\title{
A SABINE'S GULL IN SOUTHERN SASKATCHEWAN
}

\section{by Herbert W. R. Copland}

\section{Manitoba Museum of Man \& Nature, Winnipeg.}

Madge Lake in the Duck Mountain Provincial Park in Saskatchewan was calm the evening of Friday, June 20, 1969, with only the slightest trace of a northwest wind and a cloudy sky. The writer was located at a cottage at Ministik beach about 400 yards east of the marina and approximately 50 yards from the lakeshore. Earlier in the day gulls had been noticed on the water feeding near shore and also resting on a tiny island or boulder strewn shoal judged to be 300 yards from the lakeshore.

With leisure time available about 7 p.m. C.S.T., a walk was laken to the lake to look at the gulls. Five immature Bonaparte's Gulls were sitting feeding on the water close to shore and out over the lake two adult Bonaparte's, three Franklin's, and two Ring-billed gulls were noted flying. In the course of looking at and identifying the flying gulls, I suddenly noticed one which had a distinctly different plumage. It was blackheaded, a black triangular patch on the upper side of the outer primaries tapered acutely to the wing wrist, and adjacent to this was a white triangular area, the base of which extended across the rear edge of the wing. The balance of the wing and also the upper back were a pearly gray color much like the Franklin's Gull. The tail, lower back, and underparts were white. Color details of the bill and feet were not discernible although they appeared dark. Without a reference guide immediately at hand, I made a hasty retreat to the cottage to consult Peterson's field guide and the bird was tentatively identified as Sabine's Gull (Xema sabini), a bird that nests in the Arctic. Returning once again to the lakeshore with my wife, I saw the gull flying about and occasionally diving to the water in pursuit of food. After a short time it landed and perched on a boulder on the shoal.

Since I realized that this was a rare gull for the area, the question arose of having another bird-watcher confirm the identification. With this in mind I immediately left for the pavilion at Ministik beach with the hope that perhaps a park naturalist was stationed there. Near the telephone booth beside the parking area a park employee was approached and it was learned that there was no park naturalist. However, he pointed to two persons 50 feet away and said they were from the Museum at Regina. I strolled over and met Fred Lahrman and Lorne Scott. What a stroke of good luck to find two members of the staff of the Saskatchewan Museum of Natural History to confirm or reject an identity of a rare species!

When I returned with Fred and Lorne to the point on the lakeshore from which the gull was first noted, we thought it was still resting on the boulder strewn shoal. While Fred moved westward a short distance along the lakeshore, Lorne and I kept watch. After a short time, the bird we thought was the Sabine's arose to fly over the lake again searching for food. Fred agreed that this was indeed a Sabine's Gull. Lorne and I could now add this bird as a new species to our life lists.

The following day the writer left Madge Lake about 3:00 a.m. C.S.T. to do a breeding bird survey and didn't return until late in the morning. The Sabine's Gull was looked for in the early afternoon but was not sighted again.

Godfrey (1966) gives the breeding range of Sabine's Gull in Canada as beirg "on the arctic coast andislands", and also states: "Migration is mainly along the Pacific coast . . . Rare migrants in the Canadian interior but recorded in Alberta, Saskatchewan, Manitoba, Ontario and Quebec." 
Earlier records of this gull in Saskatchewan were of three seen on June 9, 1914, on Sandy Lake, Churchill River (Buchanan, 1920:224), and 11 found on June 11, 1960 resting on open water at the mouth of Black Bay, Lake Athabasca (Nero, 1963: 25), two specimens of which were taken. Taverner and Sutton (1934:25) considered it a rare transient at Churchill on the Arctic coast of Manitoba. Although not noted in 1930, four specimens (three females and one male) were taken in June 1931 within six miles of Churchill and adult specimens were taken in June 1933. Soper observed a single gull of this species in winter plumage on October 4, 1945 at Lake Audy in Riding Mountain National Park (1953:25) in Mani- toba. Lake Audy is approximately 85 miles southeast of Madge Lake. These lakes are similarly situated, being located on relatively small boreal escarpments in the southern sections of the respective provinces.

\section{LITERATURE CITED}

Buchanan, A. 1920. Wild life in Canada. McClelland, Goodchild and Stewart, Ltd. Toronto. $264 \mathrm{pp}$.

Godfrey, W. E. 1966. The birds of Canada. Nat. Mus. Can. Bull. 203.

Nero, R. W. 1963. Birds of the Lake Athabasca region, Saskatchewan Special Pub. No. 5, Nat. Hist. Soc., Regina.

Peterson, R. T. 1947. A field guide to the birds. Houghton Mifflin Co., Boston.

Soper, J. D. 1953. The birds of Riding Mountain National Park, Manitoba, Canada. Can. Wildl. Serv., Wildl. Mgt. Bull. No. 6, Series 2. Mimeo.

Taverner, P. A., and G. M. Sutton. 1934. The birds of Churchill, Manitoba. Annals Carnegie Mus., Vol. 23, pp. 1-83.

\section{FURTHER COMMENTS ON PRAIRIE RECORDS OF THE KNOT}

\section{by Martin K. McNicholl, Zoology Department, University of Manitoba, Winnipeg}

In a recent paper (McNicholl, 1969 a), I attempted to gather together records of the Knot (Calidris camutus) in the prairie provinces of Canada. Published additional records are now available for West Shoal Lake, Manitoba (McNicholl, 1969 b), Cold Lake, Alberta (Blokpoel, 1969), and Frank Lake and Calgary, Alberta (Smith and Wershler, 1969). In addition, I have recently been informed that a specimen collected by Sam Waller at The Pas on May 26, 1947 is in Mr. Waller's scientific collection in The Little Northern Museum (pers. corres. June and July, 1969). Also, "seven or eight" were seen at the University of Manitoba Field Station at Delta at about 9:00 a.m. on May 22, 1969 by Harold R. Bauer. Two were still present at 12:45 p.m. when the writer and Dr. Roger M. Evans visited the site with Bauer.

In my discussion on the migration routes of the Knot across the prairies, I proposed a regular flight through the western and central portions of the Alberta prairies in addition to the flight east of Manitoba proposed by Cooke (1910). Blokpoel (op. cit.) does not feel that this idea of a division of the interior flight-path into two flights can be supported. He feels that his record of a single Knot at Cold Lake, June 16, 1968, refutes the proposal because it "helps to fill" the "considerable gap in locations [of Knots] on the prairie" which I had proposed. However, it should be noted that, as Blokpoel states, Cold Lake is not in the prairies, but "within the Boreal Forest." Blokpoel suggests that the Alberta flight does not proceed over the southwestern and southcentral Alberta prairie, but rather over the eastern part of the province, because the map in Salt and Wilk (1966) clearly charts the migration of the Knot over the eastern part of the province. However, it must be pointed out that the map in Salt and Wilk is a summary map, based on the sites shown in Figure 2, p. 32 of my paper (196 a). These locations are clearly 